\title{
Education Expenditure in Aceh Local Governments An Empirical Evidence from Aceh
}

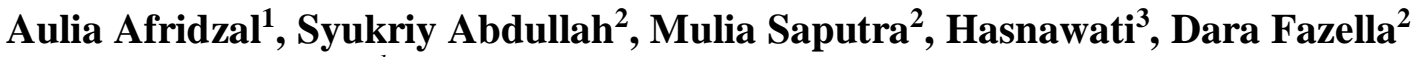 \\ ${ }^{1}$ STKIP Bina Bangsa Getsempena, Banda Aceh. \\ ${ }^{2}$ Syiah Kuala University \\ ${ }^{3}$ STKIP Bina Bangsa Meulaboh. \\ afridzal.aulia@gmail.com
}

\begin{abstract}
This study aims to examine the effect of Local Financial Independence, Last Year Budget Balance, LGs Size, and Local Revenue Growth on Education Expenditure by using data from districts and cities in Aceh for 2011-2015. The results of the study show that the Local Financial Independence and the Previous Budget Fund have a negative effect on the Education Expenditure, while the other two variables have no effect.
\end{abstract}

Keywords: Education expenditure; budget absorption; regulatory compliance; local government size; budgeting.

\section{Introduction}

Education is the responsibility of the Nation to the people, so as to fulfill this obligation the central and local should require the allocation of resources in the state budget, amounted to 20 percent for education. The Fourth Amendment 1945 Constitution Article 31 Paragraph (4) explicitly states that "prioritize the educational budget of at least twenty percent of the total national/local government (LG) budget to meet the need for national education."

The process of resource allocation into education expenditure at least 20 percent in the local budget is not a simple matter given their limited resource base area (Fahlevi, et al., 2018), especially their political interests are not always in line with the interests of public in the discussion at the local parliament (Abdullah, 2012). Budget bias, one of which can be seen from the budget variance, will affect the decisions of budget information users (Larkey \& Smith, 1989; Jones \& Euske, 1991; Mayper, et la., 1991).

Compliance with the orders of the 1945 Constitution and Law No. 20/2003 in the local budget is a necessity. The draft local government (LG) regulation on proposed local budget must first be evaluated by the Minister of Home Affairs (for provincial government) or the provincial government (for districts/city). The evaluator must sure there is the adequacy amount of the budget allocation for education spending. If it does not reach 20 percent, it can be ascertained that the draft budget is returned to the LGs for revising so the minimum allocation amounts were covered. According to Fahlevi, et al. (2018), this regulatory policy is a form of central government intervention on local governments and sometimes it is not in accordance with the conditions and needs of the local government, but becomes an important strategy in strategic public policy (Savage, 2001).

Investment in education will increase the economic growth of a country (Jalil \& Idrees, 2013). Education expenditure is very important to improve the quality of human resources (Jabbar \& Selvaratnam, 2017). The finding of Fatmayanti (2017) shows that LGs compliance with the minimum allocation for education expenditure uneven field in all districts and cities in Aceh. PECAPP study (2014) found that higher education spending in Aceh have no correlation with the quality of education output. Boateng (2014) states that any ambiguity in the determination of the determinants of educational outcomes is the cause of the decline in the quality of educational outcomes at the moment of education spending increases. 


\section{Literature Review}

\subsection{Budget and Budgeting for Education Expenditures}

The budget is the most important document in public financial management, including local government, while budgeting is the process of preparing the budget (Abdullah, 2018). The budget is the basis for the implementation of government functions and public services while at the same time demonstrating the government's priority in using public funds. Setiawan \& Rizkiah (2017) and Ritonga \& Alam (2010) states that government budgeting is strongly related to the political cycle, namely the period before, during, and after the general election. According to them, a tendency that the allocation of resources is affected by the presence or absence of elections in a fiscal year, especially when there are incumbents who run for re-election as local officials.

A resource allocation for the education sector is an important factor in improving the quality of human resources, eradicating poverty, and socio-economic development of the community (Hanushek \& Wößmann, 2007). However, budgeting for education is not always went well and according to the rules, so that can be effective and efficient in its implementation (Dufrechou, 2016), even an allocation for education is often associated with corruption (Haque \& Kneller, 2015). Ablo \& Reinikka (1998) found a misallocation and misrepresentation in government budgets, which can affect education outcomes in the longterm. According to them, in the Africa countries, allocation for education is often misleading in explaining outcomes and public policy making when institutions is weak.

\subsection{Education Expenditure Budget}

Budget performance can be interpreted as achievement of predetermined budget targets that can be measured by variances (Mayper, et al., 1989). Empirical evidence suggests that the size and efficient budget for education affects the quality of education (Gupta, et al., 1999). Determination of budget performance targets is based on systematic calculations through the planning process with the approach of technocratic, top-down, bottom-up, participatory, and political, and based on the needs and conditions of the local citizens at the time of determining priorities (Abdullah, 2018). Budget performance is a measure of the success of the LGs and the agencies in carrying out its duties and functions related to the sacrifice of public resources for the achievement of performance target.

Expenditure variance occurs because of imperfections in predicting budgetary needs. In addition to the weaknesses of human resources in predicting uncertainty, forecast errors or biases can occur due to the behavior of forecasters/budget makers who expect the budget to be inaccurate (Cassidy, et al., 1989). This behavioral aspect is very important in public budgeting, especially because it has to do with individual and political interests (Jones \& Euske, 1991; Abdullah, 2012 a).

\subsection{The Effect of Local Independence on Education Expenditure}

The fiscal decentralization policy in Indonesia based on Law No. 33/1999 and Law No. $17 / 2003$ has placed the LGs in a more independent position in making decisions for its financial management, especially for budgeting. The follow-up of these two laws is Government Regulation No. 58/2005 which states that local governments establish local regulations (Perda) and the regulation of local head (Perkada) as local regulations for budgeting, implementation, 
accountability, and its financial reporting. Therefore, local independence in financial management is a necessity as a result of the implementation of local autonomy and fiscal decentralization in Indonesia (Junita \& Abdullah, 2016). The manifestation of local financial independence is an effort to increase local revenues from local own revenue, especially in the form of local taxes and local charges (Abdullah \& Halim, 2003).

The financial independence of LGs in the region demonstrate the ability to self-finance government activities, construction, and services to using funds obtained by its own efforts (Halim, 2002). On the national average, the region's autonomy in Indonesia is relatively low when measured by the percentage of local own revenue to total expenditure area (which reflects the burden of the budget for the implementation of government functions and public services), namely about a 10 per cent.

The results of the research by Haq (2017) show that the contribution of local own revenue to local expenditure after local autonomy is significantly lower than before the implementation of local autonomy. The growth of local own revenue (PAD) after local autonomy is higher than before local autonomy. According to Haq (2017), the decrease in PAD contribution occurred because after local autonomy, the LGs tended to rely more on Transfers or Grants than the use of local own revenue (Abdullah \& Halim, 2003). Mawarni, et al. (2013) found that local own revenue had a positive effect towards capital expenditure and economic growth, while Transfer had negative effect on capital spending and affect positively on economic growth.

Fazella (2016) found that the local autonomy negatively affected the compliance of LGs in the allocation of mandatory education expenditure field, but did not find any effect of SiLPA and LG size in compliance with LGs in the allocation of education spending. Hypotheses about the effect of LGs independence on education expenditure can be expressed as follows:

$H_{1:} L G$ Independence has an effect on the education expenditure.

\subsection{The Effect of Last Year Budget Balance on Education Expenditure}

The last year budget balance (SiLPA) is cash inflows for local governments at the beginning of the fiscal year which is recognized as part of revenues in local financing budgets (Abdullah, $2013 \mathrm{~b}$ ). The remaining budget is the government-owned funds that have not been used for one fiscal year or remaining at the end of the fiscal year. SiLPA may include funds that do not have specific use in the current fiscal year and already bonded with further activities that the budget has been set in the previous year.

SiLPA is different from SILPA (Abdullah, 2013b). If SiLPA synonymous with the remaining funds coming from the budget, then SILPA is the realization at the end of current year $(n)$ that will become SiLPA budget in the next financial year $(n+1)$. This means that SiLPA is a balance fund at the end of the year and be a source of funds for financing the activities in the next year.

Funds sourced from SiLPA can be used to cover budget deficits (occurs when the realization of revenues is less than the realization of spending), contributes to the implementation of the follow-up activities, and for paying other liabilities that cannot be realized until the end of the previous fiscal year. SiLPA can come from exceeding the revenue target of PAD, transfers, other legitimate local revenues, and receipt of financing, expenditure savings, liabilities to third parties until the end of the year have not been resolved, and the remaining funds for continued activity. 
Findings in the study of Abdullah, et al. (2015) shows that SiLPA has a negative effect on budget absorption. This means that the greater the remaining amount of the previous year's budget will add to the burden of LGs for the realization of the current budget, so the more likely to not be absorbed. Activities financed from SiLPA in initial budget are activities that have not been completed in the previous fiscal year so that they are continued in the current fiscal year to achieve the performance targets that have been set. Because these follow-up activities have already provided funds (from SiLPA) and their performance targets have been set in the previous fiscal year, then at the beginning of the fiscal year can be carried out without conditions. This means that the follow-up activities can be carried out without being related to the current year budgeting which must be approved by the local parliament (DPRD).

SiLPA existence will increase the budget ceiling of the current year for the determination of incremental budget or tended increased from the previous year's budget. SiLPA carries the workload of the previous year to the current year. The greater SiLPA of the LGs in the budget year, the absorptive capacity of the relevant LGs budget for the current year will be lower. Based on this understanding, the second hypothesis can be stated as follows:

$\mathrm{H}_{2}$ : The SiLPA has an effect on Education Expenditure.

\subsection{The Effect of LGs Size on Education Budget Absorption}

The government size is an important factor in policy development and conducting public services in the local government. The size of the LG illustrates how much the burden of responsibility must be carried out by the LG to provide services to the community and carry out government functions. Some studies using total government spending as indicator of government size, both for the central/federal, and local governments (provincial and district/city).

Demography or population is important in allocating resources to the LGs (Poterba, 1997; Drew, et al., 2014; Wati \& Dawn, 2017). As an important component in the formula of block grant calculation, population is main element for determining spending amount in central government budget, directly related to the public service, including allocations to education (Ablo \& Reinikka, 199 9), and the poliatical cycle budget (Setiawan \& Rizkiah, 2017), as well as opportunistic behavior of legislatures (Abdullah, 2012). So, Hypothesis about the effect of the LG Size on Education Expenditure can be stated as follows: $H_{3}$ : LGs Size has an effect on Education Expenditure.

\subsection{The Effect of Local Own Revenue on Education Expenditure}

Revenue is the main source for financing the operational and public service of local government. Society needs for services is increasing in line with population growth and inflation that occurred continuously, and a variety of public services increases. Policy and prioritization in the allocation of resources for expenditure related to the source, especially local income, which has several types. The behavior of the budget actor in allocating budgets often lead to flypaper effect (Abdullah \& Halim, 2003; Rahmawati \& Suryono, 2015), i.e. differences in the response of expenditure on local revenue sources derived from their own revenue with the funds provided by the central government (grants).

Fiscal decentralization policy in Indonesia gives authority to local governments to collect revenue that comes from the potential that exists in the area, mainly in the form of taxes and 
levies. Own revenue is an important source to fund activities that are directly related to the local and public services, including to education (Jabbar \& Selvaratnam, 2017).

When LG revenue grows, then the space to allocate resources into spending is more open. Revenue growth associated with the development of infrastructure and public services for education (Faguet \& Sanchez, 2008). The amount of mandatory allocation according to government regulations will also be even greater, even with a fixed percentage. That is, revenue growth will lead to better levels of LG compliance, because the benchmark allocation targets for the current year tend to imitate the budget or target of the previous year (Junita \& Abdullah, 2016) and regulations set by the government at a higher level (Fahlevi, et al., 2018). So, the hypothesis about the effect of Local Revenue Growth on Education Expenditure can be stated as follows:

$H_{3:}$ Local Revenue Growth has an effect on Education Expenditure.

\section{Research Method}

This study uses secondary data obtained from local budget documents and LGs financial reports (LKPD) that have been audited by the Supreme Auditor of Republic of Indonesia (BPK RI) for districts and cities in Aceh for the period 2012-2015 with a total of 92 observations. Selection of a sample based on several criteria, namely: (1) districts and cities in Aceh receive the benefits of special autonomy allocation of funds (Otsus) and additional oil and gas sharing (TDBH) which can substitute the grants funds of the DAU or PAD to finance activities with a large value; (2) recognizing Zakat as PAD, thereby increasing the budget burden of the LGsin carrying out activities related to zakat recipients; and (3) the availability of complete data.

\section{Discussion}

\subsection{Descriptive statistics}

Table 1 presents descriptive statistics based on the results of data processing.

Table 1. Descriptive Statistics

\begin{tabular}{|l|l|l|l|l|l|}
\hline No. & Variables & Min. & Max. & Mean & Deviation Std. \\
\hline 1. & Local Independence (KD) & 0,02 & 0,25 & 0,0855 & 0,05052 \\
\hline 2. & Budget Remaining (SA) & 0,00 & 0,15 & 0,0493 & 0,03788 \\
\hline 3. & LGs Size (BP) & 4,50 & 5,77 & 5,2360 & 0,28870 \\
\hline 4 & Local Revenue Growth (PPD) & $-1,00$ & 0,41 & 0,1758 & 0,18196 \\
\hline 5. & Education Expenditure (KA) & 0,03 & 0,49 & 0,2772 & 0,10322 \\
\hline
\end{tabular}

\subsection{Regression Results}

The results of data processing using multiple linear regression models to examine the effect of Local Independence, Budget Remaining, LG Size and Local Revenue Growth on Education Expenditures in Aceh are shown in Table 2 below.

Table 2. Multiple Linear Regression Results $\mathbf{Y}$ $=0.029-0.603 \mathrm{KD}-0.554 \mathrm{SA}+0.063 \mathrm{~B}$ P - 0.017PPD + e 


\begin{tabular}{lcllll} 
t- value & 0.131 & $-2,491$ & $-1,835$ & 1,498 & $-0,302$ \\
\hline Sig. value & 0.896 & $0.015 *$ & $0.070 * *$ & 0.138 & 0.763 \\
& & & \\
\hline $\mathrm{R}=0.407$ & $\mathrm{R}^{2}=0.166 \mathrm{~A} \mathrm{dj} . \mathrm{R}^{2}=0.127$ \\
\hline $\mathrm{F}-$ value $=$ & Sig. $=0.09643$ \\
0.127 & & & \\
\hline
\end{tabular}

* Significant at $\alpha=5 \%$.

** Significant at $\alpha=10 \%$.

\subsection{Local Independence Effect on Education Expenditure}

The Local Self-Reliance regression coefficient value is -0.603 , which means that every $100 \%$ increase in local independence will reduce the performance of the LGs in realizing mandatory expenditure in education by $-60.3 \%$. These results indicate that the independence of LGs negatively affects Education Expenditure. The significance value of 0.015 which is smaller than 0.05 or $\alpha=5 \%$ indicates that this variable has a significant negative effect on education expenditure.

Local independence as measured by the percentage of PAD in total local revenues reflects the ability of local governments to fund their programs and activities independently. PAD with significant negative relationship that funding Education does not use the PAD, but other sources such as grants (general allocation, revenue-sharing, and Otsus). When the PAD increases and the budget allocation for Education $\mathrm{p}$ does not increase or even decrease, the funding for the Education does not use the PAD, but from other sources, such as the special autonomy funds.

\subsection{Effect of Last Year Budget Balance on Education Expenditure}

The regression coefficient for the Budget Remaining variable is -0.554 which means that any increase in the remaining $100 \%$ of the budget will reduce the performance of the LG in realizing the education budget of $-55.4 \%$. Statistically, this effect is expressed as significant with a significance value (Sig. value) of 0.070 or lower than the $10 \%$ significance level or $\alpha=$ $10 \%$. This negative relationship shows that when the rest of the higher budget, the education expenditure will decrease.

The remaining budget of the previous year will add to the current year's budget burden (Abdullah, et al., 2016, 2017) so that it has an impact on the ability of local governments/SKPD to absorb or achieve budget performance. This relates to the concept of performance management explaining that organizational capacity is not increasing, while the burden of the relevant organization is getting heavier, the performance of the organization is predicted to decline. That is, for a LG/agency, a large budget is not always beneficial when the capacity to realize the budget is not enough. Niskanen's prediction (1971) that agency tends to be a budget maximizer does not always hold when organizational resources cannot account for its performance.

Education expenditure is indirectly linked with the politics of the budget, especially for the incumbent (Ritonga \& Alam, 2010). The increase in budget allocations for grants and social assistance during the campaign period and the incumbent local elections participate competition for another term implications for the decrease in the budget allocation for education expenditure. When at the end of the year there are the rest of the budget comes from thrift expenditure or overrun on the revenue target area, then at the beginning of the next year (the 
year of the campaign and local elections) will increase the amount for grants and social assistance.

\subsection{The Effect of LG Size on Education Expenditure}

The regression coefficient of the LG Size variable is 0.063 which means that every increase of $100 \%$ the size of the LG will increase the performance of LGs in realizing the education budget of $6.3 \%$. However, the amount of Sig. value 0.138 indicates that this variable has no significant influence on the 5\% level. That is, the magnitude of LG Size variable does not affect the education expenditure variable in Aceh.

The results of this study are different from the findings of Liando \& Hermanto (2017) who find that the greater number of the population, the greater the budget required for improving the quality and quantity of public facilities. Previously, Sasana (2011) also found the positive effect on the number of population on public expenditure.

Public finance theory states that the greater the LG Size (the total population), then the amounts of money that allocated to education expenditure will be increase. It is caused by demand to vary the shape and quality of public service that must be met by the Government, especially for education (Poterba, 1997). On the other hand, the population has a connection with the largest local revenue in the block grants form in the form of General Allocation Funds (DAU) received from the central government, which are the main sources for financing local expenditures (Blackley, 1986). DAU massive implications for the amount of total expenditures, including expenditures for the education, which can be financed by local governments by using local own revenue.

\subsection{The Effect of Local Revenue Growth on Education Expenditure}

The value of coefficient of Local Revenue Growth is equal to -0.017 , which means that every $100 \%$ increase in local revenue growth, will reduce the level of LGs compliance to the allocation of mandatory expenditure in education by $-1.7 \%$. However, statistically, the value of Sig. value of 0.763 indicates this variable has no significant effect.

Local revenue is the main source of funding for local expenditure, including education expenditure. When it is required to allocate the resources of local governments about 20 percent for education, with the assumption that another funding source is constant, then local revenue change will be having an effect on the amount of education expenditure. That is, the local revenue growth has a positive correlation with growth and the relative percentage of expenditure for education. However, the results of this study did not find a significant influence on local income growth on education expenditure. These results are different from previous studies, such as Apriliawati \& Handayani (2016) and Solikin (2016) who found that DAU and PAD had a positive effect on local spending.

Vision and mission are political messages that are conveyed and offered by the mayor to the stakeholders of the city of Banda Aceh to be understood in conference so that stakeholders in the city of Banda Aceh understand and provide support to the mayor in carrying out their duties, obligations and authorities in building the area in accordance with the commitments political communication of the mayor of Banda Aceh, so that the development vision and mission that has been determined can run in accordance with the common goals and expectations that are able to reflect the factual conditions of the region (Nasution, et al, 2019). 
There are several explanations that can be stated for the results of this study. First, revenue growth is very small, so it does not quite mean to change the education expenditure. The increase of income correlated with the increase in spending, but the increase is not necessarily related to the increase in education expenditure, although there was an increase in the budget for education expenditure. The increase in the education expenditure budget is likely not strongly correlated with the increase in realization due to the limited capacity of agencies to implement the budget (Fahlevi, et al., 2017).

Second, there is a bias in budgeting by the bureaucracy and budget politics by parliament (Jones \& Euske, 1991; Abdullah, 2012a). Increase in revenue budget will encourage an increase in the overall amount of expenditure and allocation in some expenditure functions, but not always with the intention to be fully realized during the current year (Abdullah, et al., 2018). The remaining fund at the end of budget year will be realized at the beginning of the next fiscal year or to fund new activities that are not budgeted in a pure APBD.

Third, the measurements used may not be appropriate. The growth of local revenue using the percentage value increase in revenue, rather than a percentage of revenues over expenditures, while the measurement for budget performance of education does not use growth ratio, but the ratio of expenditure of education on realization of the total expenditure. Revenue growth should be associated with the allocation or expenditure growth for education.

Fourth, changes in local revenue of the districts/cities in Aceh is have small impact on expenditure when there is a special autonomy fund with a relatively large number of outputs and outcomes it is accepted by the districts/cities. The incentive of LGs in Aceh to increase their revenues, especially from local own revenues, are relatively low with the availability of special autonomy funds and additional oil and gas transfer funds, which amounts far above the average own revenues of these LGs. However, the effect of the special autonomy fund needs to be analyzed more deeply considering the changing policies in terms of its management, so that there is a hidden background from the public which is the reason for budget actors in the Aceh Government, specifically the Aceh Province House of Representatives (DPRA) and the Governor of Aceh.

\section{Conclusion}

This research is the determinant test performance Education Budget in Aceh, namely the Local Financial Independence, Previous Fund Balance, LG Size, and Growth of Revenue using data districts and cities in Aceh for the years 2011-2015. Based on the results can be concluded that the Local Financial Independence and the Previous Fund Balance negatively affect education expenditure, while LG Size and Local Revenue Growth has no effect on Education Expenditure.

Some limitations of this study were (1) Data that used in this research are secondary data from districts and cities in Aceh whit the special autonomy status for the year 2012 to 2015, so it should not be generalized to areas that do not implement special autonomy status; (2) the low value of the coefficient of determination of $16.60 \%$ indicates that there are many other variables that have not been included in this research model; and (3) the selection of research variables and operational definitions it is not perfect, especially variable LG Size and Local Revenue Growth, so that it is not successfully proven to have a significant effect on Education Expenditure. 


\section{References}

Abdullah, S. (2012a). Legislative Opportunistic Behavior and Affecting Factors: Empirical Evidence from LG Budgeting in Indonesia. Dissertation (Unpublished). Yogyakarta:

Doctoral Program in Economics, Faculty of Economics and Business, Gadjah Mada University.

. (2012b). Variance of Local Expenditure and Variance Budget: An Introduction. Available online at: https://syukriy.wordpress.com/2016/11/26/anal-varianBudgetpemerintah-daerah-penjelas-empiris-dari-perspektif-keagenan/ 05/20/2018).

.(2013a). APBD changes. Available online at: https://syukriy.wordpress.com/2013/04/22/perchange-apbd/ (Access 5/20/2018).

. (2018). Local Government Budgeting: Theory, Regulation and Practice. Banda Aceh: PT. Aceh Media Graphic.

Diermeier, D. and Pohan F. (2011). Bargaining over the budget. Social Choice and Welfare 36 (3/4): 565-589.

Directorate Autonomy Region, Deputy Local Development and Autonomy. (2011). Final Report: Study of the Quality of Revenue and Expenditure Budget Expenditures (APBD). Jakarta: Ministry of Home Affairs.

Dollery, Brian, Byrnes, J., and Crase, L. (2008). Australian Local Government Amalgamation: A Conceptual Analysis Population Size and Scale Economies in Municipal Service Provision. Australasian Journal of Local Studies 14(2): 167-175.

Drew, Joseph, Kortt, M., A., and Dollery B. (2014). Economies of Scale and Local Government Expenditure: Evidence from Australia. Administration \& Society 46(6) 632-653.

Dufrechou, P., A. (2016). The Efficiency of Public Education Spending in Latin America: A Comparison to High-Income Countries. International Journal of Educational Development 49: 188-203

Jetter, M., and Parmeter, C., F. (2017). Does Urbanization Mean Bigger Governments? The Scandinavian Journal of Economics (Accepted Article): 1-35.

Jones, LR and Euske, KJ. (1991). Strategic Misrepresentation in Budgeting. Journal of Public Administration Research and Theory: J-PART 1(4): 437-460.

Junita, A. (2018). Determinants of Local Government Budget Performance with Budget Changes as Mediating and Information Technology as Moderating: Study of Agencies of the Local Government in Aceh. Dissertation (Unpublished). Medan: Doctor Program in Accounting, Faculty of Economics and Business, University of North Sumatra.

Keefer, P., and Khemani, S. (2005). Democracy, Public Expenditures, and the Poor: Understanding Political Incentives for Providing Public Services. The World Bank Research Observer 20(1): 1-27.

Larkey, PD and Smith, RA. (1989). Bias in the Formulation of Local Government Budget Problems. Policy Sciences 22(2): 123-166.

Lestari, Soraya, Abdullah, S., and Basri, H. (2014). Influence of Pure Expenditure and Allocation of Expenditures on Changes to Kabuapaten/City Budget Absorption in Aceh. Postgraduate Master of Accounting Journal, Syiah Kuala University 3(3): 80-89.

Lewis, B., D. (2016). Legislature Size, Local Government Spending, and Public Service Access in Indonesia. Working Papers in Trade and Development No. 2016/16. 
Liando, Ike, I., and Hermanto, S., B. (2017). Th Determinants of Local Expenditure of District/City in East Java. Accounting Science and Research Journal 6(6): 1-22.

Mahmudi. (2010). Analysis of Local Government Financial Statements. Second edition. UPP STIM Yogyakarta: YKPN.

Nasution, H., et. al. (2019). Commitment of Political Communication in the Mayor of Banda Aceh. Budapest International Research and Critics Institute Journal, 2(1): pp. 7-16.

Ritonga, I., T., and Alam, M., I. (2010). Do Incumbent Utilizing the Revenue Budget and Expenditure (Budget) for Running Back in Local Head Election. Paper Presented at the 13th National Accounting Symposium at Jenderal Soedirman University, Purwokerto.

Robbins, D. (2005). Administrative Discretion: Its Use in Budgetary Analysis. Public Administration Quarterly 29(1/2): 186-200.

Rubin, I. (1996). Budgeting for Accountability: Municipal Budgeting for 1990s. Public Budgeting \& Finance (Summer): 112-132.

Ruhmaini and Abdullah, S. (2017). Factors that Influence SKPK Direct Expenditure Budget in Central Aceh District. Journal of Economics and Development 8(1): 54-65.

Ruwaida, Darwanis, and Abdullah, S. (2015). Factors Affecting the Realization of Education Expenditure Budget in Aceh Province. Journal of Accounting Administration Postgraduate Program Unsyiah 4(4): 101-110.

Sasana, H. (2011). Analysis of Determinants Expenditure Area in District/City of West Java Province in Autonomy and Fiscal Decentralization Era. Journal of Business and Economics (JBE) 18(1): 46-58.

Savage, J., D. (2001). Budgetary Collective Action Problems: Convergence and Compliance under the Maastricht Treaty on European Union. Public Administration Review 61(1): 43-53.

Schick, A. (2003). The Role of Fiscal Rules in Budgeting. OECD Journal on Budgeting 3(3): 7-34.

Schneier, E. (2004). Emerging Patterns of Legislative Oversight in Indonesia, in Pelizzo, Riccardo \& Rick Stapenhurst (Editors). 2004. Legislatures and Oversight. Washington, DC: The International Bank for Reconstruction and Development/The World Bank.

Setiawan, D., and Rizkiah, F. (2017). Political Budget Cycles in Municipalities: Evidence from Indonesia. International Journal of Business and Society 18(3): 533-546.

Smith, R., W., and Bertozzi, M. (1998). Principals and Agents: An Explanatory Model for Public Budgeting. Journal of Public Budgeting, Accounting \& Financial Management 10(3): 325-353.

Wati, M., R. and Fajar, C., M. (2017). The Influence of Local Original Revenue and Balancing Funds on Bandung City Local Expenditures. Journal of Accounting Studies 1(1): 63-76.

Zakiati, Y., M. (2016). The Influence of Budget Planning and Politics of Budgeting on Budget Changes and the Impact on Budget Expenditures on the SKPK of the Sabang City Government. Thesis (Unpublished). Banda Aceh: Postgraduate Program at Syiah Kuala University.

Zarinah, M., Darwanis, and Abdullah, S. (2016). Effect of Budget Planning and Human Resources on Budget Absorption Rate SKPD in North Aceh District. Postgraduate Master of Accounting Journal of Syiah Kuala University 5(1): 90-97. 